\title{
The efficiency of the top Mega yacht builders across the world: a financial ratio-based data envelopment analysis
}

\author{
Merendino, A, Deidda Gagliardo, E \& Coronella, S
}

Author post-print (accepted) deposited by Coventry University's Repository

Original citation \& hyperlink:

Merendino, A, Deidda Gagliardo, E \& Coronella, S 2018, 'The efficiency of the top Mega yacht builders across the world: a financial ratio-based data envelopment analysis', International Journal of Management and Decision Making, vol. 17, no. 2, pp. $125-147$.

https://dx.doi.org/10.1504/IJMDM.2018.10009551

DOI 10.1504/IJMDM.2018.10009551

ISSN $1462-4621$

ESSN $1741-5187$

Publisher: Inderscience

Copyright $(\subseteq$ and Moral Rights are retained by the author(s) and/ or other copyright owners. A copy can be downloaded for personal non-commercial research or study, without prior permission or charge. This item cannot be reproduced or quoted extensively from without first obtaining permission in writing from the copyright holder(s). The content must not be changed in any way or sold commercially in any format or medium without the formal permission of the copyright holders.

This document is the author's post-print version, incorporating any revisions agreed during the peer-review process. Some differences between the published version and this version may remain and you are advised to consult the published version if you wish to cite from it. 
Dr. Alessandro Merendino (corresponding author)

Centre for Business in Society, Faculty of Business and Law, Coventry

University, Priory Street, CV1 5FB, Coventry, United Kingdom

Corresponding author: alessandro.merendino@ coventry.ac.uk

Prof. Enrico Deidda Gagliardo

Department of Economics and Management, University of Ferrara, Italy.

Email: dddnrc@unife.it

Prof. Stefano Coronella

Department of Economics and Law Studies, Parthenope University of Naples, Italy. Email: stefano.coronella@uniparthenope.it

\begin{abstract}
This research provides an application of a non-parametric analytic technique (Data Envelopment Analysis, DEA) in measuring the performance of the mega yacht sector. It analyses the efficiency of the top mega yacht companies across the world in 2005-2013 by offering a model useful for comparing inefficient shipbuilders with the efficient ones. This paper adopts an output-oriented version of DEA based on financial ratios where inputs are not utilised. In order to handle missing data, we test and compare two different techniques: the deletion one and the multiple linear regression analysis (MLRA). We find that DEA can be a complement or alternative tool to ratio analysis to evaluate corporates' performance. We also find that the most efficient shipbuilders are those based in the most prosperous countries. Finally, the MLRA efficiency scores are more reliable and consistent with the firms' annual reports and financial ratios.
\end{abstract}

Keywords: Data Envelopment Analysis, Efficiency, Financial Ratios, Mega Yacht Sector

Acknowledgments: The authors are grateful to the Editor Prof. Madjid Tavana and the anonymous reviewers for their constructive comments. We also thank Prof. Maureen Meadows (Centre for Business in Society, Faculty of Business and Law, Coventry University, UK) for her invaluable support and feedback and the attendants of the Faculty of Business Law (Coventry University) Internal Research Conference for their insightful comments.

\title{
Biographical notes:
}

Dr Alessandro Merendino is a researcher at the Centre for Business in Society, Coventry University, United Kingdom. He is also a chartered accountant (a member of Institute of Chartered Accountants in England and Wales) and internal auditor. His research interests lie in the area of corporate governance, the board of directors, big data, listed companies, the mega yacht sector and mega events (including Olympics and FIFA events). He is also a reviewer of a 
number of international journals and a member of International Corporate Governance Society and the British Academy of Management.

Prof. Enrico Deidda Gagliardo is a professor in Private and Public Management and Accounting at the Department of Economics and Management, University of Ferrara, Italy. His expertise is mainly based on public and private management with a focus on performance of both public administration and private companies. He is interested in analyzing financial statements of public and private companies and state-owned businesses. He is one of the members of the committee established by the Minister of Public Administration in Italy in order to revise the accounting principles. He is also a $\mathrm{PhD}$ Supervisor, a qualified chartered accountant and internal auditor.

Prof. Stefano Coronella is a professor in Management at Parthenope University of Naples, Italy, where he teaches 'Financial and operational Accounting' and 'Accounting History'. He is the scientific director of the 'Italian Journal of Accounting' ('Rivista Italiana di Ragioneria'), the 'Historica' and 'Re-edition of the past'; the last two belong to the RIREA, one the most important Italian publisher. $\mathrm{He}$ is a director and was a treasurer of the Italian Society of Accounting History. He has many publications, among the others, about television industry, financial statements analysis, account receivables, M\&A, group of companies and accounting history.

\section{Introduction}

The mega yacht sector includes all large and leisure ships with a length exceeding 250 feet. The mega yacht sector represents an important industry around the world for many reasons. For instance, this sector plays a compelling role and remarkably contributes to the economies of a number of nations and of many other sectors, like port businesses and services, tourism, engineering, design and fashion (Bruni and Carcano, 2009). For instance, this sector contributed $£ 273 \mathrm{~m}$ in gross value added (GVA) to the UK in 2016 (SuperYacht Business, 2016), $€ 485$ bn ( $£ 440$ bn) to the European Union with an employment rate of $5.5 \mathrm{~m}$ people (Blonk, 2015). Estimations are that by 2020 the GVA will have increased to $€ 590$ bn (Blue Growth Strategy, 2017). Another factor that shows the importance the mega yacht sector around the world is partnerships that shipyards seek to establish with other companies in order to remain competitive and to tackle the substantial challenges that the mega yacht sector has experienced over the last decade (SuperYacht International, 2015). Since the global financial 
crisis in 2008 the biggest shipbuilders have undergone substantial changes (Ritvala et al., 2014) in terms of ownership composition, alternative international partners, relocation of plants in developing countries and new M\&As. For instance, some shipyards have established new partnerships with some of the world's top luxury brands, including Gucci, Hermès and Chanel, in order to increase the prestige of mega yachts (Smith, 2011) and to attract more customers. As a result, companies have implemented new corporate decisions in order to cope with global financial distress and to improve competition (Badiezadeh and Saen, 2014). The competition (Wu et al., 2014) amongst the largest mega yacht companies has increased due to these novel corporate arrangements, technological improvements and development of new ports' regulations (Gagliardo, 2008; Quagli and Ramassa, 2011). Until recently, mega yacht companies were more focused on growing the components of their assets in order to accomplish their goals for development; however, they are now more attentive to increasing their profitability (Merendino, 2013, 2014). This requires the determination and management of different factors that have a vital role in the profitability (Halkos and Salamouris, 2004) of mega yacht companies in the new competitive environment.

The objective of this study is to evaluate and compare the efficiency of the top mega yacht builders across the world during the period 2005-2013 by using financial ratio-based data envelopment analysis (DEA) approach. The period 2005-2013 has been chosen for two reasons. First, we want to consider an adequate period before and after the financial crisis in accordance with previous research (Costa, 2012); secondly, this is the time period for which most companies had made their financial reports publicly available, at the time we undertook data gathering. We want to show that financial accounting ratios and non-parametric techniques (like DEA) can be used as a complement to each other for the evaluation of companies' performance (Rouse et al., 2002). It is also generally accepted that the efficiency of a company is multidimensional in its nature (Paradi et al., 2011) and financial ratios are able to capture 
this multifaceted dimension (Gibson, 2010). As Halkos and Salamouris (2004) stated "in order to provide reasonable conclusions from comparative performance of a subset of companies, it is fundamental that a comparison is conducted amongst companies operating in homogenous market". For this reason, we selected the biggest mega yacht builders across the world, as they operate with the same type of customers, designers, engineers and stakeholders in order to provide yachts exceeding 250 feet. The companies were selected on the basis of the top 30 global ranking published annually by Global Order Book which has been one of the main guides to the superyacht industry since 1992. This research offers an application of the outputoriented version of DEA based on financial ratios without inputs in the mega yacht sector. The modelling follows that of Fernandez-Castro and Smith (1994) that takes a modified DEA model to find efficient scores. Furthermore, although many studies adopting DEA to handle missing data apply the deletion technique (Halkos and Tzeremes, 2007; Fu et al., 2010; Demirbag et al., 2016; Dharmapala and Zaibet, 2006; Hua and Bian, 2008), a growing number of research has applied a particular approach, i.e., multiple linear regression analysis (MLRA). In order to find the most reliable results, in this study we employ and compare both techniques (deletion and MLRA).

The present study makes contributions to existing literature empirically and conceptually. First, we make an empirical contribution through our world-wide sample of large mega yacht companies. The selection of these shipyards is significant and novel in allowing us to analyse the efficiency of the mega yacht sector which is a growing industry operating worldwide. As regards methodological contributions, this research offers a compelling approach in applying DEA to evaluate the efficiency of shipyards, i.e., an output-oriented version of DEA based on financial ratios in which inputs are not utilised. This technique allows us to examine companies' performance and their financial ratios in conjunction with firm efficiency. Furthermore, this research offers an additional methodological contribution on how to handle missing data in a 
sample of companies where DEA is utilised. In order to identify the best way to manage missing data, we test and compare two approaches: the deletion technique (Kuosmanen, 2008) and MLRA (Chen et al., 2014). While the deletion approach represents the traditional approach to dealing with missing data (Charles and Kumar, 2012), MLRA is considered an alternative method to manage all cases with missing values (Chen et al., 2014). We find that MLRA provides unbiased results (i.e., efficiency scores) which are in line with companies' annual reports and financial ratios.

The remainder of the paper is organised as follows: In the next section, a literature review of the mega yacht sector and similar DEA studies is presented. Afterwards, the DEA method is described. The methodology and the financial ratios used and the mega yacht builders included in the sample are presented next. The empirical results, including descriptive statistics, findings shown by using the deletion technique and MLRA, and the feasible targets are analysed. The final section discusses the conclusions and implications of this study, and a future research agenda is presented.

\section{Literature review}

\subsection{Mega yacht: the sector}

This industry has some peculiar features that make it a unique and interesting case to study. First, mega yacht builders are characterised by technological innovation and a high level of specialisation (Baan, 1996). This means that shipbuilders, to be competitive, should invest continuously in soft and hard innovation; where the former refers to product and process innovation (Amar, 2002) and the latter refers to marketing policies (Castelló, 2012), intangible investments (den Hertog et al., 1997) and organisational issues. Examples include fostering networking, improving management practices and customising services (Howells, 2000). 
Secondly, the mega yacht sector is tightly connected with luxury that is "constantly on the move' [Kapferer, (2008), p.96] and is 'always changing its appearance' [Mortelmans, (2005), p.504]. Mega yachts are expected to have:
a excellent quality
b very high prices
c scarcity and uniqueness
$\mathrm{d}$ aesthetics and polysensuality
e ancestral heritage and personal history
f superfluousness (Heine, 2012).

Finally, some scholars (Francesetti, 2008; Bruni and Carcano, 2009) argue that the mega yacht sector has an anti-cyclical nature, meaning that it is not affected by financial crisis cycles, because this luxury sector is strongly related to the number and the wealth of millionaires known as ultra high net worth individuals (UHNWIs) In fact, the number and the amount of their assets keep increasing despite financial crises, suggesting that recession does not impinge on the mega yacht sector. However, from an analysis of financial statements it emerges that the biggest shipyards across the world have witnessed either a loss or a significant reduction in sales triggering dangerous and worrying consequences especially after 2010 (Merendino, 2013, 2014).

Annually, Global Order Book releases the ranking of shipbuilders based on numbers and length of mega yacht orders (ShowBoats International, 2015). Table 1 shows the 2015 ranking. Italy has been playing a pivotal role internationally in this sector since 2001. Indeed, Italian 
companies are ranked in the tops 3 , and 10 out of 30 builders that are based in this country, meaning that it is the worldwide leader in terms of production of luxury ships followed by the Netherlands. In addition, East Europe, Turkey and China have recently been ranked in the top 30 mega yacht builders, meaning that they continue to grow and become more competitive.

Table 1 Top 30 Mega Yacht Builders 2015

\begin{tabular}{|l|l|l||l|l|l|}
\hline $\begin{array}{l}\text { 2015 } \\
\text { Rank }\end{array}$ & Shipbuilders & Country & $\begin{array}{l}\mathbf{2 0 1 5} \\
\text { Rank }\end{array}$ & Shipbuilders & Country \\
\hline 1 & Azimut/Benetti & IT & 16 & Christensen & US \\
\hline 2 & SanLorenzo & IT & 17 & Cerri-Baglietto & IT \\
\hline 3 & Ferretti Group & IT & 18 & Palmer Johnson & US \\
\hline 4 & Sunseeker & GB & 19 & Sunrise Yachts & TR \\
\hline 5 & Lürssen & DE & 20 & Privilege Yard & IT \\
\hline 6 & Amels / Damen & NL & 21 & Abeking & DE \\
\hline 7 & Feadship & NL & 22 & The Italian Sea Group & IT \\
\hline 8 & Princess Yachts & GB & 23 & Mengi Yay & TR \\
\hline 9 & Heesen Yachts & NL & 24 & Oruçoglu & TR \\
\hline 10 & Horizon & TW & 25 & Heysea & CN \\
\hline 11 & Gulf Craft & US & 26 & Mondo Marine & IT \\
\hline 12 & Fipa & IT & 27 & Dream Ship Victory & TR \\
\hline 13 & Overmarine & IT & 28 & Perini Navi & IT \\
\hline 14 & Alexander Marine & US & 29 & Hatteras & US \\
\hline 15 & Oceanco & NL & 30 & Oyster Marine & GB \\
\hline
\end{tabular}

Source: Elaboration from Global Order Book 2015

Index of Countries: CN: China; DE: Germany; GB: Great Britain; IT: Italy; NL: The Netherlands; TR: Turkey; TW: Taiwan; US: United States.

As regards the demand-side of the mega yacht industry, the clientele is mostly represented by the so-called UHNWIs, those who account for net assets over $\$ 30$ million excluding their main properties. In terms of their geographical origin, Russians, Asiatic and North Americans are the main super yacht owners with a fall of Latin Americans (Wealth-X Report, 2017) in 2017. It has been estimated that the number and the wealth will continue to increase over the next 
future (Hodgson, 2017), implying that the mega yacht sector will continue to grow and flourish in the next few years.

\subsection{DEA and mega yacht}

Little research has been conducted to date about the efficiency of the mega yacht sector. Costa (2012) evaluates efficiency and productivity of intellectual capital in the Italian yacht sector, which represents the first attempt to study the efficiency in the mega yacht sector. Some studies (Tongzon, 2001; Cullinane et al., 2006; Ablanedo-Rosas et al., 2010) aim at analysing port efficiency that is indirectly connected with the mega yacht sector, since harbours should provide added services to mega yacht owners to attract them in order to increase and improve the performance of ports. Ablanedo-Rosas et al. (2010) examine the efficiency of Chinese ports by using multiple financial ratios and combining them into a single measure of efficiency. Their study utilises a DEA technique that is not so often applied to efficiency studies, i.e., DEA based on financial ratios without inputs. They find that the most efficient ports correspond to the highest ratios (e.g., current and quick ratios, and return on equity). However, there are few attempts to measure firms' performance by analysing financial ratios. In this respect, for example, Halkos and Salamouris (2004) and Yu et al. (2013) apply this non-parametric method (i.e., DEA) with no use of inputs by observing accounting ratios in two different competitive markets: commercial banking and the computer industry. It emerges that the role of financial ratios is paramount to analyse companies' efficiency, especially in competitive environments, because the combination of DEA and ratios is a powerful tool to measure quality management efficiency and to provide suggestions to improve inefficient quality management (Kuah et al., 2010), especially in complex and competitive sectors like the mega yacht one. For this reason, the present research analyses the top 30 mega yacht firms across the world during the period 2005-2013 by using the financial ratio-based DEA, which represents an alternative or 
complement to ratios analysis for the evaluation of a firm's efficiency (Halkos and Salamouris, 2004).

\section{DEA}

DEA is a non-parametric approach aimed at measuring the relative efficiency of decisionmaking units (DMUs) performing the same or similar tasks (Charnes et al., 1978). Different variations of DEA have been developed; among them the most widely applied are DEA-CCR (Charles et al., 1978) and DEA-BCC (Banker et al., 1984). The main idea is that DEA compares units (branches, companies, departments) taking into account resources used and output (goods and/or services) provided. Thus, the DEA model discerns between efficient and inefficient units (Cooper et al., 2007) resulting in a fundamental tool for managers to evaluate the inefficiencies within the company and then to implement strategies to improve the productivity of inefficient units, increasing profitability and diminishing operating costs (Sherman and Zhu, 2006).

In order to evaluate the efficiency of mega yacht shipbuilders, the present study adopts the financial ratio-based DEA model, particularly the Fernandez-Castro and Smith's (1994) and Halkos and Salamouris's (2004) approaches where, in contrast with the original DEA model proposed by Charnes et al. (1978), inputs are not specified. The main idea is that inputs are considered similar and equal' [Halkos and Salamouris, (2004), p.205] for all companies since they perform in the same market for goods (viz. mega yachts). Accordingly, Fernandez-Castro and Smith (1994) state that when DMUs operate in the same market or sector, selling the same products or services, "the inputs to the firms can be considered immaterial, as they can be assumed to equal for all [...] The interest of the analyst is then in finding the companies which secure what are in some sense the 'best' financial ratio (output) amongst the firm observed" [Fernandez-Castro and Smith, (1994), p.241]. Indeed, from this perspective financial ratios 
reflect and encompass inputs. It follows that the DEA model adopted in this research is focused on outputs (i.e., financial ratios).

The output-oriented and financial ratio-based DEA model is defined as follows (Halkos and Salamouris, 2004; Ablanedo-Rosas et al., 2010): there are $n$ DMUs, where each DMUi $(\mathrm{i}=1,2, \ldots, n)$ generates $q$ outputs $y_{i j}(\mathrm{j}=1,2, \ldots, q) . \alpha i$ is the DEA coefficient associated with $D M U i$. The DEA model is the following linear program for each company:

$\operatorname{Max} \lambda_{0}$

Subject to

$$
\sum_{i=1}^{n} \alpha_{i}=1
$$

$$
\begin{gathered}
\sum_{i=1}^{n} y_{i j} \alpha_{i} \geq y_{i 0} \lambda_{0} \quad \mathrm{j}=1,2, \ldots ., \mathrm{q} \\
\left.\Lambda_{0} \geq 0, \alpha_{i} \geq 0 . \mathrm{i}=1,2, \ldots ., \mathrm{I}\right)
\end{gathered}
$$

The efficiency score for the each DMU is given by $\Phi_{0}=\frac{1}{\lambda_{\mathrm{c}}}$ and it is positive and less than or equal to 1 . DMUs with $\Phi_{0}$ equal to 1 are considered as efficient; whereas DMUs with $\Phi_{0}$ score less than one are deemed as inefficient.

Traditional DEA literature (Charnes et al., 1978; Banker et al., 1984) states that all inputs and outputs should be positive and certain. However, scholars have been trying to relax the restriction of the DEA model and to handle missing data by adopting different typologies of methods, viz. the deletion technique (Kuosmanen, 2008), multiple linear regression (Chen et al., 2014) or the fuzzy approach (Kao and Liu, 2000). The present research applies and 
compares two approaches for handling missing data, i.e. the deletion technique (Kuosmanen, 2008) and multiple linear regression analysis (Chen et al., 2014). The deletion approach is utilised since it is the traditional approach to cope with missing data (Charles and Kumar, 2012); and multiple linear regression analysis is applied because it represents a general method that can handle manage all cases with missing values (Chen et al., 2014).

Specifically, this study adopts the following phases.

Phase A. All those DMUs for which it is not possible to retrieve financial statements or financial ratios from databases for the entire period analysed are deleted from the sample.

Phase B. With the remaining DMUs, we verify whether financial ratios are presented for each year. In the case of a DMU that does not have any data for one or more years but has it for the remaining years, we delete this DMU for that particular year. The reasons a company (DMU) has missing data for a given year are that either the financial statement is not published for that year or the company is established after that year. For instance, The Italian Sea Group was established in 2013, so the only financial statement available is for 2013; for this reason, The Italian Sea Group DMU is deleted from the sample from 2005 - 2012.

Phase C. All ratios for all remaining DMUs are checked. We delete the DMU where it is not possible to calculate its ratios because they would have been biased; e.g. the Fipa's ROE in 2013. Fipa registered a loss (negative nominator) in 2013 and has negative equity (negative denominator) resulting in a positive ROE that is biased and inconsistent.

Phase D1. By taking the above steps, the resulting sample is composed of both DMUs with all financial ratios for the entire period under analysis and DMUs with some financial ratios missing for some years. In order to manage this missing data and consistent-with the literature (Scheffer 2002) we delete DMUs even in the case where they exhibit some missing financial ratios for one year. 
Phase D2. An alternative approach of deletion applied in Phase D1 is used in order to manage missing data. In particular, in the case of the few DMUs with missing financial ratios for one or more years, Chen et al.'s (2014) approach is adopted, i.e. Multiple Linear Regression Analysis (MLRA). The latter is a statistical method, which predicts the values of a dependent variable given a set of explanatory variables (Pindyck and Rubinfeld, 1998). The MLRA approach (Chen et al., 2014), used to estimate missing values, is developed as follows:

Step 1. The variable with missing values is considered as the dependent variable and the remainder as independent ones; proceed to Step 2.

Step 2. If a DMU has other independent variables with existing missing values, they are excluded from the analysis; otherwise to obtain the regression equation MLRA is used (then proceed to Step 3). If all values of remaining independent variables of the current DMU are missing, it is necessary to replace the dependent variable of the current DMU with the mean of the variable excluding the DMUs with missing values (then proceed to Step 3).

Step 3. The predicted values using the regression equation in Step 2 are calculated; go back to Step 1 until all missing values are estimated.

Consequently, the present research compares results by applying both the deletion method in Phase D1 and MLRA in Phase D2. It follows that in the case of the former, a drop in the number of DMUs has occurred. Furthermore, Phase D2 represents an alternative to Phase D1.

A potential problem arises because some ratios may register negative values. Since some companies in the sample exhibit negative financial ratios (e.g. ROE, ROA) a constant value is added to every negative value in order to transform them into positive (Yildirim and 
Philippatos, 2007; Pasiouras et al., 2009; Ablanedo-Rosas et al., 2010) and 'to ensure that the reference group of DMUs performs no worse than a reference [...]' shipbuilder 'on the ratio where the DMUo in the study has negative performance' [Ablanedo-Rosas, (2010) p.353].

\section{Methodological Approach: Sample and Variables}

The present research deals with the top 30 mega yacht builders across the world by using financial ratio-based DEA which examines simultaneously multiple financial ratios by combining them into a single measure of shipbuilders' efficiency. This study analyses the top shipbuilders published by the Global Order Book 2015 during the period 2005-2013.

It is worth pointing out that it is not possible to expand the period of analysis, because financial statements are not available. By using Orbis and Fame to retrieve financial statements and financial ratios, financial statements of 17 companies have been analysed; the remaining 13 shipbuilders that do not have them available ${ }^{1)}$ are deleted from the sample (Phase A) ${ }^{\mathrm{i}}$. Secondly, 6 out of 17 companies do not exhibit any data for one or more years, which means they are deleted from the sample (Phase B). Indeed, for a given year, the financial statement of a given DMU is not available, resulting in the deletion of this unit. Furthermore, 3 out of 17 companies exhibit biased values of ratios; thus, when they present biased data they are deleted from the sample (Phase C). For instance, in 2010 Cerri exhibits a positive ROE due to both negative numerator (loss) and denominator (equity). By using DEA as a method, our results are able to identify if and how the financial crisis has affected performance and efficiency of the shipyards.

Due to the complexity of analysing the shipbuilders' financial performance, the variables (i.e. outputs) analysed are financial ratios. Financial ratios are highly significant for mega yacht companies, because they offer organisations a standardised method for comparing 
their performance, investments, finance, costs and revenues with the other competitors worldwide. Additionally, given the fast-paced mega yacht environment, financial ratios will give further impetus to companies and competitors to adjust or rectify some corporate decisions or investments, including opening new plants or yards in a different country than the headquarter. Financial ratios can be categorised into four basic types: profitability ratios, activity ratios, liquidity ratios and leverage or solvency ratios (Vickers, 2006). For each of these categories, we have calculated at least one ratio has been calculated to measure the efficiency score, resulting in seven different ratios. It follows that a more comprehensive view of the companies is obtained, since all the categories of ratios have been analysed.

\section{PROFITABILITY RATIO}

1. Return on Equity $(\mathrm{ROE})=$ income/book value of shareholders' equity ${ }^{\mathrm{ii}}$. It shows the ability of management to use shareholders' resources to generate net income (Arditti, 1967; Easton, 2004; Baker and Powell 2009).

2. Return on Assets $(\mathrm{ROA})=$ net income/assets. It indicates the company's ability to generate net income by using its assets (Bettis and Hall, 1987; Gibson 2010).

\section{ACTIVITY RATIOS/TURNOVER RATIOS}

3. Inventory Turnover $=$ cost of goods sold / Inventory. It measures managers' ability to maintain the right level of inventory during a certain period of time (Saunder and Cornett, 2003; Hill et al., 2014).

\section{LIQUIDITY RATIO}


4. Current ratio $=$ total current assets/total current liabilities. It measures the ability of a company to pay off its current liabilities in the short term (Libby, 1975; Chen and Yuan, 2004; Gibson 2010).

5. Quick ratio $=($ cash + accounts receivable $) /$ current liabilities. It represents a variant of current ratio, by considering that inventory is not as liquid as cash and accounts receivable (Beaver, 1968; Gallagher and Andrew, 2007).

\section{LEVERAGE RATIO/SOLVENCY RATIOS}

6. Debt ratio $=$ total liability/total equity. It examines the balance between debts (including loans, mortgages, etc.) and equity (Anderson et al., 2004; Gibson, 2010).

7. Solvency ratio $=$ total liabilities/total assets. It evaluates the relationship between the total liabilities and total assets (Beaver, 1966; Patra, 2006).

\section{Empirical Results}

Table 2 describes these financial ratios for all companies from 2005 to 2013 . The descriptive statistics refer to Phase D1, meaning that they are calculated considering both negative values and observations without any missing data.

The ROE mean witnessed its highest level in 2008 (21.05\%) and has registered a positive trend since 2005; whereas during the recovery period (2009-2013) the ROE mean dropped considerably, especially in 2011 when it was $-34.14 \%$. This means that in the precrisis period (2005-2006) and at the crisis peak (2007-2008) the top shipbuilders performed better than during the recovery period (2009-2013), because the negative effects of the global recession emerged a few years after the peak (2007-2008). Indeed, after this period mega yacht 
orders decreased significantly due to the change in the type of luxury goods UHNWIs were purchasing (from leisure boats to jewellery, art and vintage cars). ROA assumed the same trend as ROE, meaning that firms' ability to generate net income by using their assets deteriorated in the last five years of the analysis.

Current and quick ratios have the same positive trend for the period analysed. However, the former decreased in 2013 while the quick ratio increased, because the inventories reduced and companies registered more cash and equivalents, and accounts receivable, than during the years before. This may be due to three factors: more mega yachts were sold, as witnessed by a slight increase in ROE in 2013; some plants and superfluous assets were disinvested resulting in an increase in cash and accounts receivable; shipbuilders obtained new internal funds from shareholders (equity) and restructured their debts with financial institutions. Indeed, the debt ratio decreased in 2013, meaning that firms were improving their financial position. 
Table 2 Descriptive Statistics

\begin{tabular}{|c|c|c|c|c|c|c|c|c|c|}
\hline & 2013 & 2012 & 2011 & 2010 & 2009 & 2008 & 2007 & 2006 & 2005 \\
\hline \multicolumn{10}{|l|}{ ROE } \\
\hline Number of observations & 14 & 16 & 17 & 15 & 17 & 16 & 16 & 16 & 15 \\
\hline Mean & -10.16 & -22.28 & -34.14 & -7.90 & -30.40 & 21.05 & 13.96 & 17.38 & 12.86 \\
\hline Median & 0.23 & 2.29 & 0.56 & 3.70 & 8.93 & 21.00 & 12.77 & 15.42 & 3.88 \\
\hline Standard Deviation & 48.51 & 103.02 & 116.99 & 48.22 & 138.90 & 27.23 & 22.38 & 21.71 & 26.78 \\
\hline $\operatorname{Max}$ & 59.58 & 54.46 & 64.50 & 68.30 & 29.89 & 90.77 & 54.29 & 53.30 & 68.73 \\
\hline Min & -166.70 & -413.13 & -482.32 & -153.85 & -572.78 & -33.66 & -42.60 & -32.30 & -49.67 \\
\hline \multicolumn{10}{|l|}{ ROA } \\
\hline Number of observations & 14 & 16 & 17 & 15 & 17 & 16 & 16 & 15 & 15 \\
\hline Mean & -1.38 & 1.23 & -1.02 & -3.82 & -0.12 & 7.82 & 5.57 & 6.04 & 4.85 \\
\hline Median & 0.16 & 1.79 & 0.01 & 0.47 & 0.58 & 4.44 & 3.26 & 3.03 & 1.98 \\
\hline Standard Deviation & 10.00 & 10.20 & 9.92 & 15.86 & 9.19 & 9.99 & 7.39 & 8.37 & 10.36 \\
\hline $\operatorname{Max}$ & 13.45 & 18.80 & 14.09 & 18.11 & 13.56 & 40.38 & 21.62 & 32.73 & 39.65 \\
\hline Min & -24.32 & -20.82 & -30.19 & -46.04 & -28.91 & -2.64 & -5.67 & -4.06 & -9.55 \\
\hline \multicolumn{10}{|c|}{ INVENTORY TURNOVER } \\
\hline Number of observations & 14 & 16 & 17 & 15 & 17 & 16 & 16 & 16 & 15 \\
\hline Mean & 12.84 & 4.67 & 3.30 & 7.40 & 4.77 & 4.51 & 5.72 & 4.71 & 2.83 \\
\hline Median & 3.04 & 3.65 & 3.21 & 2.82 & 1.55 & 3.28 & 3.69 & 3.15 & 1.81 \\
\hline Standard Deviation & 33.51 & 5.49 & 2.53 & 14.77 & 7.14 & 4.02 & 7.03 & 4.67 & 2.70 \\
\hline Max & 133.13 & 20.00 & 8.40 & 60.38 & 29.56 & 12.62 & 28.55 & 19.71 & 10.73 \\
\hline Min & 0.21 & 0.20 & 0.02 & 0.38 & 0.57 & 0.25 & 1.00 & 0.87 & 0.04 \\
\hline \multicolumn{10}{|l|}{ CURRENT RATIO } \\
\hline Number of observations & 14 & 16 & 17 & 15 & 17 & 16 & 16 & 16 & 15 \\
\hline Mean & 1.26 & 1.61 & 1.55 & 1.89 & 1.42 & 1.29 & 1.29 & 1.19 & 1.20 \\
\hline Median & 1.16 & 1.02 & 1.28 & 1.31 & 1.27 & 1.15 & 1.10 & 1.06 & 1.08 \\
\hline Standard Deviation & 0.55 & 1.39 & 1.01 & 1.52 & 0.98 & 0.42 & 0.56 & 0.45 & 0.39 \\
\hline Max & 2.56 & 6.60 & 4.42 & 6.66 & 4.96 & 2.12 & 3.06 & 2.66 & 2.35 \\
\hline
\end{tabular}




\begin{tabular}{|c|c|c|c|c|c|c|c|c|c|}
\hline Min & 0.66 & 0.65 & 0.34 & 0.63 & 0.45 & 0.59 & 0.48 & 0.78 & 0.81 \\
\hline \multicolumn{10}{|l|}{ QUICK RATIO } \\
\hline Number of observations & 14 & 16 & 17 & 15 & 17 & 16 & 16 & 16 & 15 \\
\hline Mean & 0.68 & 0.57 & 0.62 & 0.84 & 0.54 & 0.50 & 0.66 & 0.55 & 0.51 \\
\hline Median & 0.63 & 0.64 & 0.59 & 0.46 & 0.39 & 0.38 & 0.45 & 0.47 & 0.46 \\
\hline Standard Deviation & 0.41 & 0.32 & 0.51 & 0.86 & 0.36 & 0.37 & 0.55 & 0.41 & 0.38 \\
\hline Max & 1.59 & 1.09 & 2.33 & 3.15 & 1.16 & 1.38 & 2.22 & 1.74 & 1.65 \\
\hline Min & 0.17 & 0.10 & 0.01 & 0.09 & 0.08 & 0.08 & 0.14 & 0.10 & 0.14 \\
\hline \multicolumn{10}{|l|}{ DEBT RATIO } \\
\hline Number of observations & 14 & 16 & 17 & 15 & 17 & 16 & 16 & 16 & 15 \\
\hline Mean & 3.42 & 3.10 & 5.53 & 4.24 & 7.59 & 2.61 & 2.93 & 8.37 & 9.27 \\
\hline Median & 2.04 & 2.24 & 1.68 & 1.98 & 1.39 & 1.75 & 1.53 & 2.99 & 4.02 \\
\hline Standard Deviation & 5.67 & 2.44 & 10.35 & 7.14 & 19.98 & 3.07 & 3.86 & 17.67 & 16.10 \\
\hline Max & 22.32 & 10.64 & 43.72 & 30.31 & 86.45 & 11.74 & 13.10 & 75.63 & 66.33 \\
\hline Min & -3.78 & 0.37 & 0.15 & 0.42 & 0.34 & 0.00 & 0.00 & 0.08 & 0.06 \\
\hline \multicolumn{10}{|l|}{ SOLVENCY RATIO } \\
\hline Number of observations & 14 & 16 & 17 & 15 & 17 & 16 & 16 & 16 & 15 \\
\hline Mean & 47.43 & 52.02 & 80.88 & 42.81 & 44.07 & 35.76 & 34.99 & 35.79 & 31.80 \\
\hline Median & 40.94 & 47.20 & 45.67 & 42.70 & 40.77 & 26.61 & 26.15 & 25.13 & 23.23 \\
\hline Standard Deviation & 28.82 & 35.81 & 132.39 & 30.74 & 31.81 & 25.32 & 24.89 & 37.93 & 33.16 \\
\hline Max & 120.78 & 148.79 & 584.83 & 125.44 & 100.77 & 85.51 & 84.45 & 165.86 & 136.30 \\
\hline Min & -4.48 & -9.40 & -5.64 & -3.30 & 1.16 & 7.86 & 7.55 & 0.01 & 0.02 \\
\hline
\end{tabular}


Table 3 shows the efficiency score for each shipbuilder between 2005 and 2013 after the deletion of DMUs that present missing data (Phase D1). The first column of the table represents the DMUs rank; this enables us to compare the results obtained by applying MLRA. Furthermore, for each year, the second column presents the companies' names and the third one the efficiency scores. 
Table 3 Efficiency scores - Deletion technique (Phase D1)

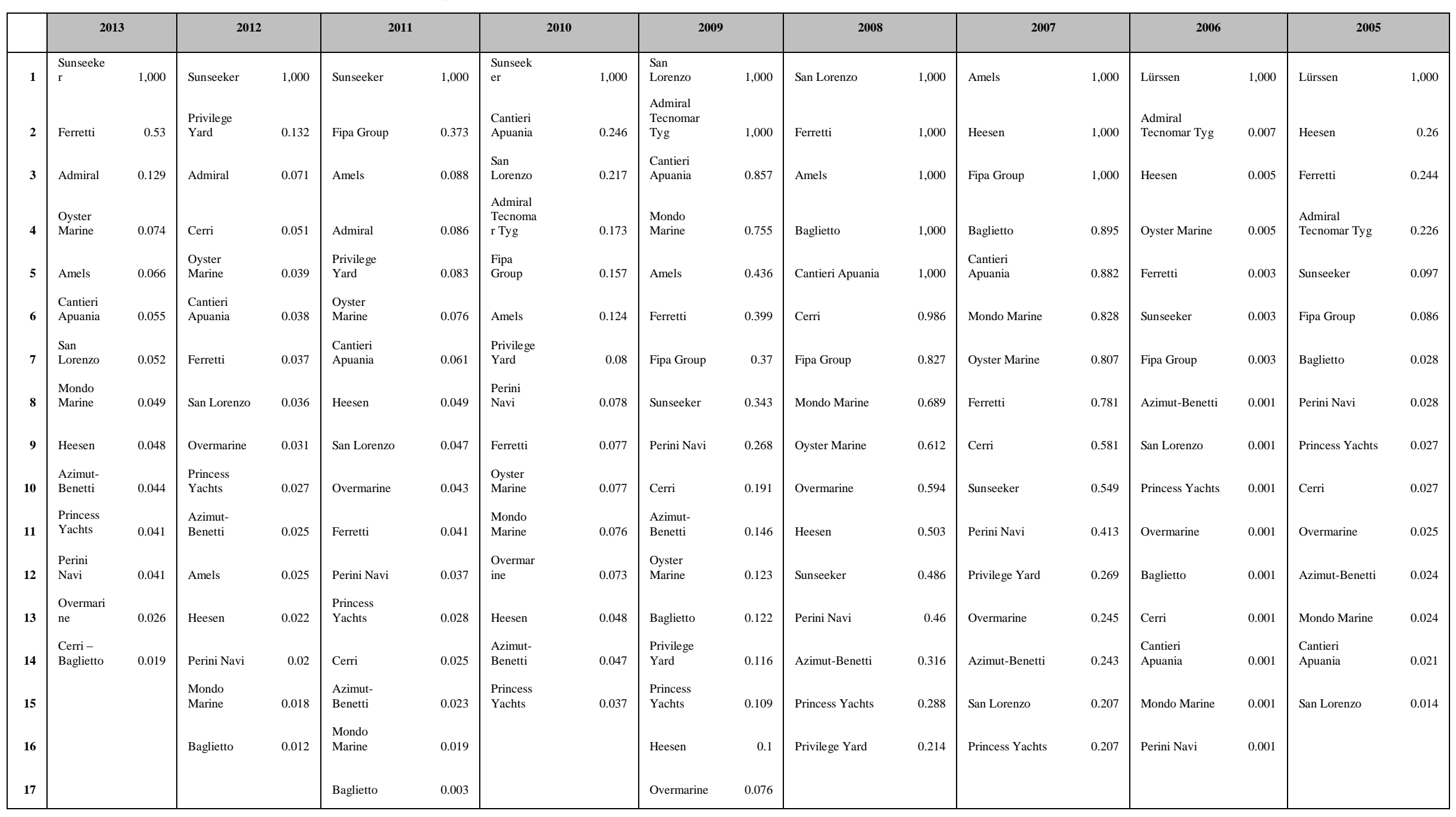


Results show that only one shipbuilder proves to be efficient between 2010 and 2013, and between 2005 and 2006, respectively Sunseeker (UK) and Lürssen (DE). Furthermore, during the period 2007 - 2009, efficient shipbuilding companies increased from two to five, e.g. San Lorenzo (IT) and Amels (NL). Two conclusions can be drawn. First, during the period 2007-2009 more than half of the efficient companies are Italian shipbuilders, confirming the leadership of Italy in terms of both mega yacht orders and efficiency (Costa 2012; Merendino, 2014). Secondly, during the peak of the financial crisis (2007 and 2008), a greater number of efficient shipbuilders can be observed, while during the recovery period all companies witness a worsening of their performance, as confirmed in the descriptive statistics (Table 2). Indeed, during 2010-2013, only Sunseeker, which is the largest volume mega yacht builder in the UK, is the most efficient among the top shipbuilders across the world.

Table 4 shows the efficiency scores for each shipbuilder between 2005 and 2013 after using the approach of Chen et al. (2014), i.e. multiple linear regression to estimate missing values (Phase D2). 
Table 4 Efficiency scores - MLRA (Phase D2)

\begin{tabular}{|c|c|c|c|c|c|c|c|c|c|c|c|c|c|c|c|c|c|c|}
\hline & \multicolumn{2}{|c|}{2013} & \multicolumn{2}{|l|}{2012} & \multicolumn{2}{|c|}{2011} & \multicolumn{2}{|l|}{2010} & \multicolumn{2}{|l|}{2009} & \multicolumn{2}{|c|}{2008} & \multicolumn{2}{|l|}{2007} & \multicolumn{2}{|l|}{2006} & \multicolumn{2}{|c|}{2005} \\
\hline 1 & Sunseeker & 1 & Sunseeker & 1 & Sunseeker & 1 & Sunseeker & 1 & $\begin{array}{l}\text { Abeking \& } \\
\text { Rasmussen }\end{array}$ & 1 & San Lorenzo & 1 & Amels & 1 & Lürssen & 1 & Lürssen & 1 \\
\hline 2 & $\begin{array}{l}\text { The Italian } \\
\text { Sea Group }\end{array}$ & 0.262 & $\begin{array}{l}\text { Abeking \& } \\
\text { Rasmussen }\end{array}$ & 1 & $\begin{array}{l}\text { Abeking \& } \\
\text { Rasmussen }\end{array}$ & 1 & $\begin{array}{l}\text { Abeking \& } \\
\text { Rasmussen }\end{array}$ & 0.295 & Baglietto & 1 & Amels & 1 & Fipa Group & 1 & $\begin{array}{l}\text { Admiral tecnomar } \\
\text { tyg }\end{array}$ & 0.009 & Heesen & 0.181 \\
\hline 3 & $\begin{array}{c}\text { Admiral } \\
\text { tecnomar tyg }\end{array}$ & 0.085 & Privilege Yard & 0.546 & $\begin{array}{l}\text { Privilege } \\
\text { Yard }\end{array}$ & 0.546 & $\begin{array}{l}\text { Cantieri } \\
\text { Apuania }\end{array}$ & 0.246 & $\begin{array}{l}\text { Admiral tecnomar } \\
\text { tyg }\end{array}$ & 1 & $\begin{array}{l}\text { Abeking \& } \\
\text { Rasmussen }\end{array}$ & 1 & $\begin{array}{l}\text { Abeking \& } \\
\text { Rasmussen }\end{array}$ & 1 & Oyster Marine & 0.006 & Ferretti & 0.17 \\
\hline 4 & $\begin{array}{l}\text { Oyster } \\
\text { Marine }\end{array}$ & 0.074 & Cerri & 0.5 & Cerri & 0.5 & San Lorenzo & 0.217 & San Lorenzo & 0.319 & $\begin{array}{l}\text { Cantieri } \\
\text { Apuania }\end{array}$ & 1 & $\begin{array}{l}\text { Cantieri } \\
\text { Apuania }\end{array}$ & 0.852 & Heesen & 0.006 & $\begin{array}{c}\text { Admiral } \\
\text { tecnomar tyg }\end{array}$ & 0.158 \\
\hline 5 & Amels & 0.066 & San Lorenzo & 0.33 & San Lorenzo & 0.33 & $\begin{array}{c}\text { Admiral } \\
\text { tecnomar tyg }\end{array}$ & 0.174 & Cantieri Apuania & 0.302 & Cerri & 0.914 & Mondo Marine & 0.761 & Feadship & 0.006 & Sunseeker & 0.067 \\
\hline 6 & $\begin{array}{l}\text { Cantieri } \\
\text { Apuania }\end{array}$ & 0.055 & Oyster Marine & 0.325 & $\begin{array}{l}\text { Oyster } \\
\text { Marine }\end{array}$ & 0.325 & Fipa Group & 0.157 & Mondo Marine & 0.287 & Fipa Group & 0.807 & Cerri & 0.589 & Fipa Group & 0.004 & Fipa Group & 0.06 \\
\hline 7 & San Lorenzo & 0.052 & $\begin{array}{l}\text { Admiral tecnomar } \\
\text { tyg }\end{array}$ & 0.324 & $\begin{array}{c}\text { Admiral } \\
\text { tecnomar tyg }\end{array}$ & 0.324 & Lürssen & 0.142 & Ferretti & 0.243 & Feadship & 0.482 & Ferretti & 0.581 & Ferretti & 0.004 & Feadship & 0.027 \\
\hline 8 & $\begin{array}{l}\text { Mondo } \\
\text { Marine }\end{array}$ & 0.049 & Lürssen & 0.288 & Lürssen & 0.288 & Amels & 0.124 & Amels & 0.164 & $\begin{array}{l}\text { Mondo } \\
\text { Marine }\end{array}$ & 0.436 & Sunseeker & 0.573 & Sunseeker & 0.003 & Perini Navi & 0.02 \\
\hline 9 & Heesen & 0.048 & Cantieri Apuania & 0.288 & $\begin{array}{l}\text { Cantieri } \\
\text { Apuania }\end{array}$ & 0.288 & Privilege Yard & 0.08 & Fipa Group & 0.129 & Ferretti & 0.433 & Oyster Marine & 0.382 & Baglietto & 0.003 & $\begin{array}{l}\text { Princess } \\
\text { Yachts }\end{array}$ & 0.019 \\
\hline 10 & $\begin{array}{l}\text { Azimut- } \\
\text { Benetti }\end{array}$ & 0.044 & Amels & 0.218 & Amels & 0.218 & Perini Navi & 0.078 & Sunseeker & 0.113 & Baglietto & 0.403 & Feadship & 0.378 & San Lorenzo & 0.002 & Cerri & 0.019 \\
\hline 11 & $\begin{array}{l}\text { Princess } \\
\text { Yachts }\end{array}$ & 0.041 & Azimut-Benetti & 0.215 & $\begin{array}{l}\text { Azimut- } \\
\text { Benetti }\end{array}$ & 0.215 & Ferretti & 0.077 & Cerri & 0.093 & Perini Navi & 0.34 & Heesen & 0.334 & Perini Navi & 0.002 & Overmarine & 0.018 \\
\hline 12 & Perini Navi & 0.041 & Perini Navi & 0.207 & Perini Navi & 0.207 & Oyster Marine & 0.077 & Perini Navi & 0.088 & Sunseeker & 0.325 & Perini Navi & 0.297 & Mondo Marine & 0.002 & $\begin{array}{l}\text { Azimut- } \\
\text { Benetti }\end{array}$ & 0.017 \\
\hline 13 & $\begin{array}{l}\text { Abeking \& } \\
\text { Rasmussen }\end{array}$ & 0.04 & Fipa Group & 0.206 & Fipa Group & 0.206 & Mondo Marine & 0.076 & Privilege Yard & 0.064 & $\begin{array}{l}\text { Oyster } \\
\text { Marine }\end{array}$ & 0.272 & Baglietto & 0.26 & Cerri & 0.002 & $\begin{array}{l}\text { Mondo } \\
\text { Marine }\end{array}$ & 0.017 \\
\hline 14 & Ferretti & 0.034 & Feadship & 0.193 & Feadship & 0.193 & Overmarine & 0.073 & LÜRSSEN & 0.06 & $\begin{array}{l}\text { Azimut- } \\
\text { Benetti }\end{array}$ & 0.195 & Overmarine & 0.259 & Cantieri Apuania & 0.002 & Baglietto & 0.015 \\
\hline 15 & Feadship & 0.032 & Mondo Marine & 0.188 & $\begin{array}{l}\text { Mondo } \\
\text { Marine }\end{array}$ & 0.188 & Feadship & 0.059 & Oyster Marine & 0.055 & Overmarine & 0.17 & Azimut-Benetti & 0.217 & Princess Yachts & 0.001 & $\begin{array}{l}\text { Cantieri } \\
\text { Apuania }\end{array}$ & 0.014 \\
\hline 16 & Overmarine & 0.026 & Ferretti & 0.185 & Ferretti & 0.185 & Heesen. & 0.048 & Azimut-Benetti & 0.05 & Heesen & 0.165 & San Lorenzo & 0.212 & Overmarine & 0.001 & San Lorenzo & 0.01 \\
\hline 17 & $\begin{array}{c}\text { Cerri- } \\
\text { Baglietto }\end{array}$ & 0.019 & Overmarine & 0.175 & Overmarine & 0.175 & Azimut-Benetti & 0.047 & Feadship & 0.048 & $\begin{array}{l}\text { Princess } \\
\text { Yachts }\end{array}$ & 0.142 & Princess Yachts & 0.202 & Azimut-Benetti & 0.001 & & \\
\hline 18 & & & Princess Yachts & 0.172 & $\begin{array}{l}\text { Princess } \\
\text { Yachts }\end{array}$ & 0.172 & Princess Yachts & 0.037 & Princess Yachts & 0.038 & $\begin{array}{l}\text { Privilege } \\
\text { Yard }\end{array}$ & 0.111 & Privilege Yard & 0.135 & & & & \\
\hline 19 & & & Heesen & 0.146 & $\begin{array}{l}\text { Heesen } \\
\text { Yachts }\end{array}$ & 0.146 & & & Heesen & 0.036 & & & & & & & & \\
\hline 20 & & & Baglietto & 0.08 & Baglietto & 0.08 & & & Overmarine & 0.031 & & & & & & & & \\
\hline
\end{tabular}


It emerges that by adopting these two different approaches to handling missing data, some changes may occur in the efficiency scores. Ferretti and Fipa, which are the second companies registering the highest efficiency score with the deletion approach, drop to the lowest part of the ranking with the MLRA. The latter is likely to be more accurate measure and in line with companies' performance. Indeed, Ferretti registers an excessive value of inventory turnover (133.13) and the average of all companies is 12.84 implying an ineffective buying and an investment with a rate of return of zero. FIPA registers the lowest level of ROE (-482\%), a negative ROA (-8.16\%), a low inventory turnover (0.5) and a low solvency ratio (1.8) compared with other companies analysed ${ }^{\mathrm{iii}}$. Furthermore, it is plausible to assume that by adding new observations to the sample, the sample becomes less biased and these newly added firms appear to be more efficient than the sample obtained by using the deletion approach. For instance, in 2009 the companies having the highest efficiency score in 2009 through the deletion technique are San Lorenzo and Admriral; however, by adding three more companies, San Lorenzo is replaced by Aberking \& Rasmussen and Cerri but still remains in the top rank.

During the financial crisis peak (2007-2008) and 2009, the number of efficient companies increased, whereas before the recession and during the recovery period the efficient companies are one and two. This is due to the fact that during the recovery period the shipbuilders have tried to react to a decrease in mega yachts' orders by disinvesting in plants, changing ownership composition, and replacing directors and managers. These radical strategies require time before their positive effects can impact on companies and on financial reports.

Moreover, during the period 2004-2013 the lowest efficiency scores are mainly associated with Italian companies, apart from Princess Yacht that registers the worst score in 2010. This is deeply at odds with the Global Order Book rank stating that Italy is the country 
that registers the highest mega yacht orders in the world. This suggests that while Italy is the leading country in terms of the number of mega yachts produced, on the other hand it has the least efficient companies among the top mega yacht builders. On the other hand, the English and Germany shipbuilders are able to invest their resources efficiently during the recovery and pre-crisis periods, respectively.

The companies that experience change in ownership are Ferretti, Sunseeker, Hessen, Admiral tecnomar and Cantieri Apuiana. From our analysis, it emerges that even after its acquisition by a Chinese company, Sunseeker is the most efficient shipbuilder. On the other hand, Ferretti and Hessen present a lower level of efficiency, especially after the acquisition by the new shareholders in 2011 and 2008 respectively. This may mean that the M\&A was a paramount strategy to save these company but it does not seem that these companies are efficiently managed. As regards Admiral tecnomar and Cantieri Apuiana, in 2013 they merged to form The Italian Sea Group. Even though their efficiency scores did not increase after the M\&A, the new group of companies reached the second position in efficiency in 2013. This suggests that, in this instance, the M\&A helped the two companies to perform better at a time when all the other competitors were witnessing a worse performance.

\section{Discussion and conclusions}

In this study, an application of DEA to the biggest mega yacht firms was performed, by using financial ratios as output measures in the suggested model for the time period 2005-2013. Two approaches to handle missing data were used, namely the deletion technique and MLRA. Finally, from the analysis we calculated the optimal ratios (output) level for inefficient companies in 2013.

Some interesting implications emerge from this analysis. First, this research shows that managing missing data through MLRA (Phase D2) is more accurate and reliable than using the 
deletion techniques (Phase D1), because the efficiency scores are in line with financial reports and their related financial ratios. In fact, Ferretti was categorised as the second most efficient company in 2012 through the deletion approach, even though it witnessed a negative trend in all ratios; on the other hand, by running MLRA it registered a low efficiency score, positioning the company in the lowest part of the rank. Therefore, MLRA results are more reliable than the deletion technique. Indeed, the deletion technique may provide biased results (i.e., efficiency scores), which are not sustained by companies' reports and financial ratios.

Second, the 2015 Global Order Book rank, which is based on the number and length of mega yachts orders, does not reflect companies' efficiency. It means that shipbuilders receiving the highest orders numbers of mega yacht are not necessarily performing efficiently. For instance, our study shows that Azimut-Benetti and Ferretti, the top shipbuilders across the world in terms of mega yacht orders, may be not the most efficient companies.

Third, Italy is not the best performing country in terms of efficiency. Indeed, Italian shipbuilders appear to be efficient between 2006 and 2009, before the financial crisis affected the mega yacht sector. After 2010 British and German companies register the highest efficiency score. That is an interesting result, because it seems that the efficiency trend of these shipbuilders reflects the economic structure of their own countries. Indeed, the UK and Germany are the most powerful economic countries within the European Union (Knowles, 2013). It follows that if Italian companies want to keep abreast with English and German shipbuilders, they should invest their resources more efficiently by comparing their strategies to those of the more efficient companies (e.g., Sunseeker, Abeking and Rasmussen).

Fourth, the results confirm that the mega yacht sector is not anti-cyclical, i.e., it is deeply affected by the financial crisis as shown by the descriptive statistics (Merendino, 2016). For instance, ROE and ROA have witnessed a negative and declining trend during the period 
analysed. Although the quick ratio registers a positive trend in the last year (2013), its value is low enough (below 1) for us to consider companies to be at risk of not being able to repay current liabilities in the short run, resulting in insolvency risk.

Finally, the DEA approach is a valuable method that allows companies to compare their performance with those of their competitors and to verify the level of performance they should reach to become efficient as their competitors.

This research suffers from some limitations relating to the number of DMUs. We focused on the biggest shipbuilders across the world; future research could calculate efficiency scores for small-medium mega yacht companies. Another limitation is connected with the missing data. In order to overcome this issue, two techniques are applied and compared, namely the deletion approach and MLRA, in order to avoid biased results by applying only one technique.

This research is based on a unique study focusing on the analysis of efficient and inefficient mega yacht shipbuilders across the world. It is in line with the studies of Berger and Humphrey (1997) and Halkos and Salamouris (2004) in the application of financial ratios in DEA. It shows that financial ratio-based DEA gives insightful information for shipbuilders' management. In particular, it represents a complementary tool for managers to evaluate the performance and efficiency of their firm and competitors. Indeed, it provides each shipbuilder with a firmbenchmark that it can follow in order to increase its performance and efficiency. Future research could take into consideration other traditional financial ratios and accounting variables, such as EVA (economic value added), in order to measure the value and efficiency of a firm. Finally, future research could adopt an input-output DEA model by considering not only financial data but also information related to the board of directors, CEO turnover, employees, the organisational structure of shipyards and the number of national and international plants. 


\section{Acknowledgements}

The authors are grateful to the Editor Prof. Madjid Tavana and the anonymous reviewers for their constructive comments. We also thank Prof. Maureen Meadows (Centre for Business in Society, Faculty of Business and Law, Coventry University, UK) for her invaluable support and feedback and the attendants of the Faculty of Business Law, Coventry University, Internal Research Conference for their insightful comments.

\section{References}

Ablanedo-Rosas, J., Gao, H., Zheng, X., Alidaee, B. and Wang, H.A. (2010) 'A study of the relative efficiency of Chinese ports: a financial ratio-based data envelopment analysis approach', Expert Systems, Vol. 27, No. 5, pp.349-362.

Amar, A.D. (2002) Managing Knowledge Workers: Unleashing Innovation and Productivity, Quorum, Westport, CT.

Anderson, R.C., Mansi, S.A. and Reeb, D.M. (2004) 'Board characteristics, accounting report integrity, and the cost of debt', Journal of Accounting and Economics, Vol. 37, No. 3, pp.315342.

Arditti, F.D. (1967) 'Risk and the required return on equity', The Journal of Finance, Vol. 22, No. 1, pp.19-36.

Baan, J. (1996) Analysis of Trends in the Design of Large Mega Yachts, British Maritime Technology, Teddington.

Badiezadeh, T. and Saen, R.F. (2014) 'Efficiency evaluation of production lines using maximal balance index', International Journal of Management and Decision Making, Vol. 13, No. 3, pp.302-317.

Baker, H.K. and Powell, G.E. (2009) Understanding Financial Management: A Practical Guide, Wiley, New York.

Banker, R., Charnes, A. and Cooper, W. (1984) 'Some models for estimating technical and scale inefficiencies in data envelopment analysis', Management Science, Vol. 30, No. 9, pp.1078-1092.

Beaver, W.H. (1966) 'Financial ratios as predictors of failure', Journal of Accounting Research, Vol. 4, pp.71-111.

Beaver, W.H. (1968) 'Alternative accounting measures as predictors of failure', The Accounting Review, Vol. 43, No. 1, pp.113-122.

Berger, A.N. and Humphrey, D.B. (1997) 'Efficiency of financial institutions: International survey and directions for further research', European Journal of Operational Research, Vol. 98, pp.175-212.

Bettis, R.A. and Hall, W.K. (1982) 'Diversification strategy, accounting determined risk, and accounting determined return', Academy of Management Journal, Vol. 25, No. 2, pp.254-264. 
Blonk, T. (2015) Mapping the European Maritime Cluster, Netherlands Maritime Technology [online] https://maritimetechnology.nl/media/Mapping-the-European-maritime-cluster.pdf.

Blue Growth Strategy (2017) 'Report on the blue growth strategy towards more sustainable growth and jobs in the blue economy', European Commission [online] https://ec.europa.eu/ maritimeaffairs/sites/maritimeaffairs/files/swd-2017-128_en.pdf (accessed 12th June 2017).

Bruni, M. and Carcano, L. (2009) La Nautica Italiana. Modelli Di Business E Fattori Di Competitività, Egea, Milan.

Castelló J. (2012) 'Innovation in creating and managing experiences', in Ruiz, J.I. (Ed.): Customer Experience: A Multidimensional Vision of Experience Marketing, pp.100-107, CEMbook, Spain.

Charles, V. and Kumar, M. (2012) Data Envelopment Analysis and its Applications to Management, Cambridge Scholars Publishing, Newcastle upon Tyne.

Charnes, A., Cooper, W. and Rhodes, E. (1978) 'Measuring the efficiency of decision making units', European Journal of Operational Research, Vol. 2, No. 6, pp.429-444.

Chen, C.W.K. and Yuan, H. (2004) 'Earnings management and capital resource allocation: evidence from China's accounting-based regulation of rights issues', The Accounting Review, Vol. 79, No. 3, pp.645-665.

Chen, Y., Li, Y., Wu, H. and Liang, L. (2014) 'Data envelopment analysis with missing data: a multiple linear regression analysis approach', International Journal of Information Technology and Decision Making, Vol. 13, No. 1, pp.137-153.

Cooper, W., Seiford, L. and Tone, K. (2007) Data Envelopment Analysis, Springer, New York.

Costa, R. (2012) 'Assessing intellectual capital efficiency and productivity: an application to the Italian yacht manufacturing sector', Expert Systems with Applications, Vol. 39, No. 8, pp.7255-7261.

Cullinane, K., Wang, T., Song, D. and Ji, P. (2006) 'The technical efficiency of container ports: Comparing data envelopment analysis and stochastic frontier analysis', Transportation Research Part A: Policy and Practice, Vol. 40, No. 4, pp.354-374.

Demirbag, M., McGuiness, M., Akin, A., Bayyurt, N. and Basti, E. (2016) 'The professional service firm (PSF) in a globalised economy: a study of the efficiency of securities firms in an emerging market', International Business Review, Vol. 25, No. 5, pp.1089-1102.

den Hertog, P., Bilderbeek, R. and Maltha, S. (1997) 'Intangibles: the soft side of innovation', Futures, Vol. 29, No. 1, pp.33-45.

Dharmapala, P.S. and Zaibet, L. (2006) 'Analysis of farmer's efficiency and growth factors in oil exporting Arabian Gulf countries: the case of Oman', International Journal of Management and Decision Making, Vol. 7, No. 4, pp.377-387. 
Easton, P.D. (2004) 'PE ratios, PEG ratios, and estimating the implied expected rate of return on equity capital', The Accounting Review, Vol. 79, No. 1, pp.73-95.

Fernandez-Castro, A. and Smith, P. (1994) 'Towards a general non-parametric model of corporate performance', Omega, Vol. 22, No. 3, pp.237-249.

Francesetti, D.C. (2008) 'New challenges and the future of Italian superyacht yards', European Transport, Vol. 38, pp.32-46.

Fu, X., Helmers, C. and Zhang, J. (2010) 'The two faces of foreign management capabilities: FDI and productive efficiency in the UK retail sector', International Business Review, Vol. 21, No. 1, pp.71-88.

Gagliardo, E.D. (2008) I Cantieri Nautici Della Nautica Da Diporto. Profili Economico Aziendali e di Bilancio, Rirea, Rome.

Gallagher, T. and Andrew, T. (2007) Financial Management: Principles and Practice, Freeload Press, Paul, MN.

Gibson, C.H. (2010) Financial Reporting and Analysis: Using Financial Accounting Information, Cengage Learning, Mason.

Halkos, G. and Salamouris, D. (2004) 'Efficiency measurement of the Greek commercial banks with the use of financial ratios: a data envelopment analysis approach', Management Accounting Research, Vol. 15, No. 2, pp.201-224.

Halkos, G.E. and Tzeremes, N.G. (2007) 'Productivity efficiency and firm size: an empirical analysis of foreign owned companies', International Business Review, Vol. 16, No. 6, pp.713731.

Heine, K. (2012) The Concept of Luxury Brands, Technische Universität, Berlin.

Hill, C., Jones, G. and Schilling, M. (2014) Strategic Management Theory: An Integrated Approach, Cengage Learning, Stamford.

Hodgson, C. (2017) 'The number of super-rich 'ultra-high net worth' people is growing', Business Insider UK [online] http://uk.businessinsider.com/wealth-X-super-rich-reportincrease-in- wealth-number-of-ultra-wealthy-2017-6 (accessed 27 June 2017).

Howells, J. (2000) 'The nature of innovation in services', report presented at OECD Innovation and Productivity in Services Workshop, 31 October-3 November, Sydney.

Hua, Z. and Bian, Y. (2008) 'Performance measurement for network DEA with undesirable factors', International Journal of Management and Decision Making, Vol. 9, No. 2, pp.141153.

Kao, C. and Liu, S. (2000) 'Fuzzy efficiency measures in data envelopment analysis', Fuzzy Sets and Systems, Vol. 113, No. 3, pp.427-437.

Kapferer, J.N. (2008) The New Strategic Brand Management, Page, London. 
Knowles, L.C.A. (2013) Economic Development in the Nineteenth Century: France, Germany, Russia and the United States, Routledge, New York.

Kuah, C.T., Wong, K.Y. and Behrouzi, F. (2010) 'Application of data envelopment analysis to assess quality management efficiency', World Academy of Science, Engineering and Technology, Vol. 4, No. 10, pp.1066-1071.

Kuosmanen, T. (2008) 'Data envelopment analysis with missing data', Journal of the Operational Research Society, Vol. 60, No. 12, pp.1767-1774.

Libby, R. (1975) 'Accounting ratios and the prediction of failure: some behavioral evidence', Journal of Accounting Research, Vol. 13, No. 1, pp.150-161.

Merendino, A. (2013) 'Luxury yacht market and the anti-cyclical industry: an empirical comparison among the worldwide leaders in Italian shipyards', The Macrotheme Review, Vol. 2, No. 4, pp.27-48.

Merendino, A. (2014) 'Mega Yacht, Italian leadership and financial crisis, empirical evidence on how Italian leading companies in mega yacht sector overcome the crisis', European Scientific Journal, Vol. 10, No. 28, pp.9-35.

Merendino, A. (2016) The Mega Yacht Industry: What Financial Crisis?, Coventry University Research Blog [online] http://blogs.coventry.ac.uk/researchblog/the-mega-yacht-industrywhat-financial-crisis/ (accessed 27 December 2016).

Mortelmans, D. (2005) 'Sign values in processes of distinction: the concept of luxury', Semiotica, Vol. 157, Nos. 1/4, pp.497-520.

Paradi, J., Rouatt, S. and Zhu, H. (2011) 'Two-stage evaluation of bank branch efficiency using data envelopment analysis', Omega, Vol. 39, No. 1, pp.99-109.

Pasiouras, F., Tanna, S. and Zopounidis, C. (2009) 'The impact of banking regulations on banks' cost and profit efficiency: cross-country evidence', International Review of Financial Analysis, Vol. 18, No. 5, pp.294-302.

Patra, K. (2006) Accounting and Finance for Managers, Sarup \& Son, Delhi.

Pindyck, R. and Rubinfeld, D. (1998) Econometric Models and Economic Forecasts, Irwin/McGraw-Hill, Boston, Mass.

Quagli, A. and Ramassa, P. (2011) Creazione e Mantenimento del valore nelle aziende liguri, FrancoAngeli, Milan.

Ritvala, T., Salmi, A. and Andersson, P. (2014) 'MNCs and local cross-sector partnerships: the case of a smarter Baltic Sea', International Business Review, Vol. 23, No. 5, pp.942-951.

Rouse, P., Putterill, M. and Ryan, D. (2002) 'Integrated performance measurement design: insights from an application in aircraft maintenance', Management Accounting Research, Vol. 13, No. 2, pp.229-248. 
Saunder, A. and Cornett, M.M. (2003) Financial Institutions Management: A Risk Management Approach, McGraw-Hill, New York, US.

Scheffer, J. (2002) 'Dealing with missing data', Research Letters in the Information and Mathematical Science, Vol. 3, pp.53-160.

Sherman, H.D. and Zhu, J. (2006) Service Productivity Management. Improving Service Performance using Data Envelopment Analysis DEA, Springer, New York.

ShowBoats International (2015) Global Order Book: Definitive Guide to Superyachts Under Construction, Boat International Media, USA.

Smith, C. (2011) Gucci Luxury Yacht Charter \& Superyacht News, Charter World [online] http://www.charterworld.com/news/tag/gucci (accessed 10 February 2011.).

Superyacht International (2015) Industry Data, Report by Burgess and Boat International [online] https://www.boatinternational.com/yacht-market-intelligence/superyacht-industrydata (accessed 25th June 2015).

SuperYacht Business (2016) UK Superyacht Sector Reports Fourth Consecutive Year of Growth [online] http://www.superyachtbusiness.net/news/uk-superyacht-sector-reportsfourth- consecutive-year-growth-14737

Tongzon, J. (2001) 'Efficiency measurement of selected Australian and other international ports using data envelopment analysis', Transportation Research Part A: Policy and Practice, Vol. 35, No. 2, pp.107-122.

Vickers, F. (2006) Recession Proofing your Business, Lulu.com (accessed 13th March 2015).

Wealth-X Report (2017) Exclusive UHNWI Analysis: The World Ultra Wealth Report, 27 June [online] http://www.wealthx.com/articles/2017/the-wealth-X-world-ultra-wealth-report-2017/ (accessed 28th June 2017).

Wu, H.Q., Liu, Y.X., Zhuang, D.L. and Zhu, W.D. (2014) 'A DEA-based measurement of effectiveness of provincial image advertisement for local tourism destination: evidence from China', International Journal of Management and Decision Making, Vol. 13, No. 2, pp.192206.

Yildirim, H. and Philippatos, G. (2007) 'Restructuring, consolidation and competition in Latin American banking markets', Journal of Banking and Finance, Vol. 31, No. 3, pp.629-639.

Yu, Y.S., Barros, A. and Wu, W.H. (2013) 'Data envelopment analysis and financial ratio: a new approach to estimate the efficiency of Taiwan computer's peripheral industry', Journal of Information and Optimization Sciences, Vol. 34, No. 1, pp.69-84.

\footnotetext{
${ }^{\mathrm{i}}$ We have checked other databases, including Bloomberg and Datastream, but no suitable data is available. We, therefore, contacted by email or over the phone all the companies for which data is unavailable; some of them did not reply or unable to share their financial statements or ratios.
} 


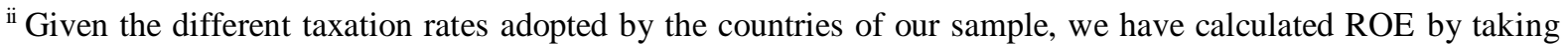
into consideration the income before taxation; by doing that our results are not affected by the diverse tax rates within our sample.

iii Data available on request. 